\title{
Analysis of Mathematical Creative Thinking Ability in Solving Mathematical Problems based Learning Styles in Class VIII Middle School Students
}

\author{
Iwan Jepri \\ Department of Mathematics Education \\ Postgraduate, State University of Medan \\ Medan, Indonesia \\ tampuboloniwa@ymail.com
}

\author{
Bornok Sinaga \\ Department of Mathematics Education \\ Postgraduate, State University of Medan \\ Medan, Indonesia \\ bornoksinaga48@gmail.com
}

\author{
Hermawan Syahputra \\ Program of Postgraduate, \\ Universitas Negeri Medan \\ Medan, Indonesia
}

\begin{abstract}
This research aims to obtain an overview of students' learning style at St. Peter's secondary school in Medan, then analyse the students' mathematical creative thinking skills in the problem of solving the study style of the accommodation, Divergent, convergent, and learning assimilation styles. In addition, interviews were conducted with students' mistakes to find students' difficulties in solving problems. Based on the results of a study of 33 students, obtained students with accommodation learning styles amounted to 5 students $(15.15 \%)$, students with divergent learning styles amounted to 8 students $(24,24 \%)$, students with convergent learning styles have 7 students $(21,21 \%)$, and students with an assimilation learning style total 13 students $39.39 \%$ ). Based on the test results of students' mathematical creative thinking abilities obtained levels of creative thinking abilities in the high category amounted to 4 students $(12.12 \%)$, the medium category numbered 7 students $21.21 \%$ ), and the low category numbered 22 students (66.66\%). From the results of interviews with the students, the style of accommodation learning has difficulty in concept indicators, procedures, and principles. In divergent learning styles students have difficulty on fact indicators, concepts, and principles. In convergent learning styles, students experience difficulties in indicator, fact, and principle procedures. In an assimilation learning style, students experience difficulties in fact, concept, and principle indicators.
\end{abstract}

Keywords-creative thinking, learning style

\section{INTRODUCTION}

The development of student skills at this time is indispensable because the development of science and technology is now possible to obtain information quickly and easily from various places in the world. To deal with these challenges, human resources are required to be reliable and able to compete globally, namely human resources with high skills and skill involving critical thinking, creative, systematic, logical, and Effective working skills. Logical, analytical, systematic, critical and creative thinking skills and ability to work together can be developed through mathematical learning. This is very possible because mathematics has a structure with a strong linkage and clearly one with the other as well as a consistent mindset. The importance of learning mathematics is not separated from its role in various areas of life.

[1] said mathematics is one of the disciplines that can improve the ability to think and argue, contribute to solving everyday problems and the world of work, and provide support in the development of science and technology. The ability to think creatively is one focus of learning mathematics. The development of the ability to think creatively indeed needs to be done because this ability is one of the abilities desired by the world of work. But what is happening in today's society is that most of the people are accustomed to being passive, lacking initiative and not being given the opportunity to express their ideas or thoughts.

The ability of creative thinking is often overlooked in learning mathematics. According to [2] that the ability to think mathematically creative has become one of the important focuses of learning developed in mathematics learning. In learning mathematics, students often face difficulties in solving complex problems or problems that are not routine. Therefore creative thinking in learning mathematics is needed to solve complicated problems. By developing mathematical creative thinking skills, students will be able to solve mathematical problems in various alternative ways.

According to [3], various studies have shown that many students have difficulties in learning mathematics as well as being weak in mathematical achievements such as mathematical creative thinking skills. One of the factors influencing learning achievement is the learning style. Identifying student learning styles by teachers is crucial. This is because students who know their type of learning style will 
adapt to learning in the classroom to succeed in learning. By identifying each student's learning style, teachers will be more easily determined which strategies, methods and approaches will be used to help students learn optimally. But if it is not appropriate to choose a learning strategy, then students will have difficulty learning [4].

With the initial understanding of the learning style, students with learning difficulties will gain more attention, so that the difficulties in learning can be minimized and learning quality can be improved. With regard to the explanation above, research needs to be done focusing on students ' creative thinking skills. In conjunction, there will be research related to creative thinking skills, mathematical problem solving, and learning style. The study aims to determine the learning style of each student, the level of creative thinking in mathematics, and the difficulties that students experience in creative thinking [5].

\section{METHOD}

This study was conducted at St. Petrus Medan Junior High School in class VIII-4. The implementation of learning is conducted for 4 (four) meetings using valid and reliable learning tools based on expert and empirical validation (statistical calculations). Math Skills Test is done 1 (one) time to know the skills of mathematical creative thinking of students. Tests of mathematical creative thinking are followed by 33 students who have participated in open-ended learning. Analysis of creative thinking skills in mathematics is reviewed based on the learning style of class VIII-4 students through open-ended learning conducted by analyzing the results of creative thinking skills test in mathematics, interviews and sheet results Observation of students ' activities with the selected subject. The subject is selected based on the learning style, which is according to the [6] consisting of an accommodation-style study, Divergent, Convergent and an assimilator for high, moderate and low levels of each indicator of thinking ability Creative in mathematics: fluency, suppleness (flexibility), novelty, and detail (elaboration).

Analysis of the test results of creative thinking skills in student mathematics, interview results, and observation sheets of student activity are conducted with data analysis steps according to [7], namely "data collection, reduction of Data (data reduction), data presentation (display data), and summary (conclusion) ". The data collection activity in this research is collecting all the necessary data in the form of a test result of creative thinking in student mathematics and observation sheet of student activity that suits the selected subject, rewriting Result of an interview activity that is still in the form of audio into writing to facilitate the analysis.

The data reduction in this study is simplifying the results of interviews into good order and removing some unnecessary things. The presentation of the data in this study includes the description of the test results of creative thinking skills in mathematics, interview results, and observations of students ' activities by the teacher. The withdrawal of conclusions on this research is done by triangulation between the test results of the creative thinking skills in mathematics, interview results, and the observation results of student activity.

\section{RESULTS}

In the following, conclusions will be drawn from the research findings data of students' creative thinking abilities in mathematics reviewed based on learning styles through an open-ended approach.

\section{A. Description of Learning Style grouping}

The grouping of student learning styles is obtained using a student-style poll instrument. The Learning Style poll consists of 28 statements representing indicators of each learning style. Each student fills a learning style poll by giving a score for each statement with the selection of scores available on each of the statement items. Results of the filling of the learning style by 33 students of class VIII-4 SMP St. Peter Medan shown in table 1

TABLE 1. RESULTS OF STUDENT LEARNING STYLE

\begin{tabular}{|c|c|c|}
\hline Nu & Learning of styles & $\begin{array}{c}\text { Number of } \\
\text { Students }\end{array}$ \\
\hline 1 & Convergen & 7 \\
\hline 2 & Divergent & 8 \\
\hline 3 & Accomodation & 5 \\
\hline 4 & Asimilation & 13 \\
\hline \multicolumn{2}{|r}{} \\
\hline
\end{tabular}

Based on table 1 it is obtained that each student occupies each style of learning Kolb \& Kolb. For the learning style of the Converger of 7 students $(21.21 \%)$, a diverger learning style of 8 students $(24.24 \%)$, accommodator learning style as many as 5 students (15.15\%), and an assimilation of 13 students (39.39\%). This means that the existence of learning style is most assimilated in comparison with other styles, then followed by the second position of the Divergent learning style, the third position of the convergent learning style, and the last one is the learning style of the accommodation.

It is supported by the research results of stating that 52 students have a tendency to learn assimilation style as many as 19 students or $36.5 \%$, divergent learning style as much as 17 learners or $32.6 \%$, learning style converger as many as 11 participants Students or $21.2 \%$, and a accomodator learning style as many as 5 learners or $9.6 \%$. This shows the most dominant learning style of assimilation.

\section{B. Description of student mathematical creative thinking skills}

The description of students mathematical creative thinking skills is obtained based on the results of tests of mathematical creative thinking skills and interviews. Mathematical creative thinking skill test in the form of 4 questions in the form of a description with the material system of two-variable linear equations. The mathematical creative thinking skill test was held on Tuesday, November 14, 2017 for 80 minutes. After tests of mathematical creative thinking skills, researchers 
analysed the mathematical skills of creative thinking, based on the indicators of mathematical creative thinking. Quantitatively, the degree of mathematical creative thinking skills of students can be seen in the following table 2 .

TABLE 2. CREATIVE THINKING SKILL LEVELS STUDENT MATHEMATICS

\begin{tabular}{|c|c|c|c|c|}
\hline Nu & $\begin{array}{c}\text { Interval of } \\
\text { value }\end{array}$ & $\begin{array}{c}\text { Numbe } \\
\mathbf{r} \text { of } \\
\text { student } \\
\mathbf{s}\end{array}$ & Percentage & $\begin{array}{c}\text { Category } \\
\text { Valuation }\end{array}$ \\
\hline 1 & $80 \leq \mathrm{SK} \leq 100$ & 4 & $12,12 \%$ & Tinggi \\
\hline 2 & $65 \leq \mathrm{SK}<80$ & 7 & $21,21 \%$ & Sedang \\
\hline 3 & $0 \leq \mathrm{SK}<65$ & 22 & $66,66 \%$ & Rendah \\
\hline
\end{tabular}

Description: $\mathrm{SK}=$ Conservation Score (student value)

BASED ON THE TABLE 2, IT CAN BE SEEN THE LEVEL OF CREATIVE THINKING SKILLS OF STUDENTS WITH THE OPEN-ENDED APPROACH. STUDENTS WITH A HIGH ABILITY OF UP TO 4 PEOPLE (12.12\%), 7 STUDENTS WITH MODERATE ABILITY (21.21\%), AND 22 STUDENTS WITH LOW ABILITY (66.66\%).

IT IS APPARENT THAT THE NUMBER OF STUDENTS IS DOMINANT IN LOW AND MEDIUM CATEGORIES. THIS SUGGESTS THAT STUDENTS ' CREATIVE THINKING SKILLS ARE STILL VERY FAR FROM WHAT TO EXPECT. AS [8] SAID THAT "INDONESIAN STUDENTS ACHIEVED THE LOWEST RANK IN CREATIVITY IN CREATIVE THINKING TESTS FOLLOWED BY EIGHT COUNTRIES". THOUGH, CREATIVE THINKING IS VERY IMPORTANT IN TODAY'S GLOBAL ERA, IT TAKES THE COMPLEXITY OF THE PROBLEM OF ALL ASPECTS OF LIFE. ACCORDING TO [9], MATHEMATICAL CREATIVE THINKING SKILLS HAS BECOME ONE OF THE IMPORTANT LEARNING FOCUSES DEVELOPED IN MATHEMATICS LEARNING.

C. Description of Mathematics creative thinking skills based on learning style

Based on research, from 33 students in grades VIII - 4 SMP Santo Petrus Medan obtained a level of creative thinking skills based on learning style is as follows.

- Students with accommodation learning styles amount to 5 people, namely students with a high category amounting to 1 person, medium category totaling 1 student and with a low category total amount 3 students.

- Students with a divergent learning style of 8 people, namely students with a high category of 1 student, category is 1 person, and with a low category of 6 people.
- Students with an assimilation learning style of 13 people, namely students in the category of 4 students, and with a low category of 9 people. In this case there are no students in the high category.

- Converging learning style is 7 students with a high category of 2 students, the assessment category is 1 student, and with a low score category of 4 students.

D. Analysis of Student Difficulties in Creative Thinking based on Learning Styles

Based on the results of the student's answer sheet analysis and interviews, students ' difficulties based on each learning style are as follows:

- Students with a learning style of accommodation have difficulties on concept indicators, procedure indicators, and principle indicators.

- Students with divergent learning styles have difficulty in fact indicators, concept indicators, and principle indicators.

- Students with the style of learning assimilation have difficulty in fact indicators, concept indicators, and principle indicators.

- Students by learning convergent have difficulty on procedure indicators, fact indicators, and principle indicators.

\section{Acknowledgment}

We thank Mr. Bornok and Hermawan to share inspiring insights on these issues, Mrs. Simbolon in SMP St. Peter who assist in conducting research, and friends of the class B3 2015 Mathematics Education Magister program who took the time for discussion.

\section{References}

[1] Hudoyo, H. (1998). Pengembangan Kurikulum Matematika dan Pelaksanaannya di Depan Kelas. Surabaya: Usaha Nasional.

[2] Peker, M. 2009. Pre-Service Teachers' Teaching Anxiety about Mathematics and Their Learning Style. Eurasia Journal of Mathematics, Science \& Technology Education, 5 (4), 335-345.

[3] Silver, E. A. 1997. Fostering Creativity through Instruction Rich in Mathematical Problem Solving and Problem Posing. Volume 29, issue 3 , p 75-80.

[4] Sugiono. (2002). Statistik untuk Penelitian. Bandung: CV. Alfabeta.

[5] TIMMS, 2012. TIMSS 2011 International Results in Mathematics. USA: TIMSS \& PIRLS International Study Center

[6] Kolb,Y. A dan Kolb, A. D 2005. The Kolb Learning Style InventoryVersion 3.1 Ohio: Hay Group.

[7] Sugiyono. 2011. Metode Penelitian Kualitatif Kuantitatif dan R\&D. Bandung: Alfabeta.

[8] Munandar, U. 2012. Pengembangan Kreativitas Anak Berbakat. Jakarta: Rineka Cipta.

[9] Siswono, T . E. Y. 2010. Penjenjangan Kemampuan Berpikir Kreatif dan Identifikasi Tahap Berpikir Kreatif Siswa dalam Memecahkan dan Mengajukan Masalah Matematika. Jurnal Pendidikan Matematika "Mathedu" 3(1) 